\title{
COMPARATIVE STUDY OF SEISMIC ANALYSIS OF MULTISTORIED BUILDING WITH SHEAR WALL AND BRACINGS
}

\author{
Pallavi G. $\mathbf{A}^{\mathbf{1}}$, Nagaraja $\mathbf{C}^{\mathbf{2}}$ \\ ${ }^{I} P G$ Student, Department of Civil Engineering, \\ Shridevi Institute of Engineering \& Technology, Tumakuru 572106, Karnataka, India \\ ${ }^{2}$ Assistant Professor, Department of Civil engineering, \\ Shridevi Institute of Engineering \& Technology, Tumakuru 572106, Karnataka, India
}

\begin{abstract}
Multistorey building would be the greater part influenced by quake constrains to seismic prone areas. The major concern in the design of the multi-storey building is the structure to have enough lateral stability to resist lateral forces, buckling, to control lateral drift and displacement of the building. The application of the shear wall system in Reinforced Concrete (RC) buildings has been widely used to minimize seismic consequences. Besides, the buildings with concentrated steel bracings system are used for the same reasons in steel structures buildings. Both of the systems have significance of the structural performance. Although both systems are used for same reasons, their effect shows unequal variations and behavior against seismic load.
\end{abstract}

In this project, G+9 storey building, along with shear wall and bracings are being considered for the analysis. The performance of building will be evaluated on the basis of following parameters -Storey displacement, Storey drift, Base shear. In this work, the shear walls and bracings are provided at different locations with the overall analysis to be carried out using Etabs9.7 software.

Keywords: ETAB, Seismic analysis, Bracings, Shear wall.

\section{INTRODUCTION}

\subsection{Overview}

An earthquake is a sudden movement of earth's crust, which originate naturally at or below the surface. In the previous twenty-eight years, considerable severe earthquakes occurred in the world at intervals of 5 to 10 years, have caused severe damages. Socio investment misfortunes have been expanded in the planet because of foundation about new urban communities to seismic tremor inclined zones. Among all the natural hazards, earthquake is most dangerous. For safety of the buildings, it is necessary that structures should have adequate lateral stability, strength, and sufficient ductility. In place to secure structures against harms previously, advancing earthquakes to extend edifices alternately should change their applications, concentrating on available states for structures and making them safe against quake may be a greater amount crucial. This work focuses on comparison of seismic analysis of $\mathrm{G}+9$ building with bracings and shear walls. The performance of the building is analyzed in Zone IV and Zone V.

For my study I considered bare frame, shear wall at corners, shear wall at sides, shear wall at core, bracings at corners, bracings at sides and bracings at core are considered.

\begin{abstract}
Shear Wall
Shear divider is a structural framework made for propped panels would otherwise called shear panels to counter the impacts of parallel load acting on the structure. Generally, shear divider is characterized as structural part equipped will stand up to consolidation of shear wall. Furthermore, pivotal load prompted by parallel load and gravity load exchange of the divider starting with different structural part. Wind seismic loads need aid practically as a relatable point loads that shear dividers are planned to convey. Shear dividers stand up in-plane loads need aid connected along its tallness. RC Multi-Storey structures need aid sufficient for opposing both different and level load.
\end{abstract}

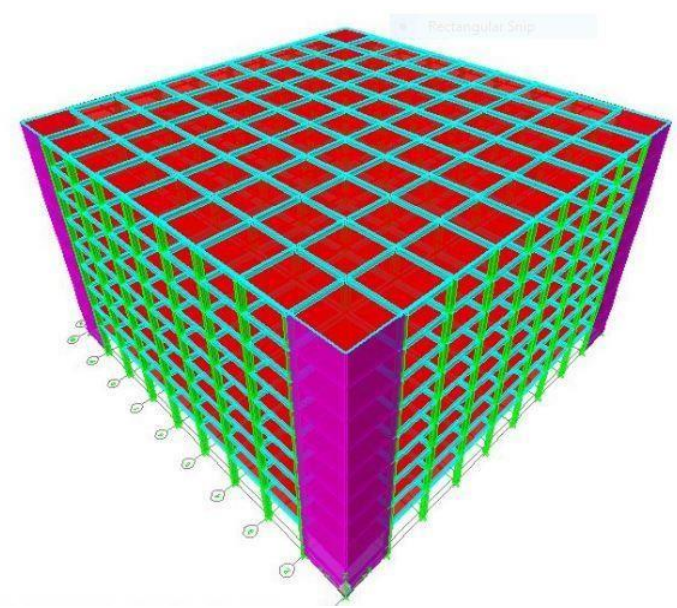

Fig 1: Shear wall at corner 
Shear walls resist two types of forces: Shear forces and Uplift forces.

Shear forces are generated in stationary buildings by accelerations resulting from ground movement and by external forces like wind and waves.

Uplift forces exist on shear walls because the horizontal forces are applied to the top of the wall.

\section{Bracings}

A bracing system is a secondary but important part of the bridge structure. Bracing system serves to stabilize main girders during construction to contribute to the distribution of load effects. Bracings are provided one or more of the following functions:

a.Control buckling.

b. Load distribution.

c. Dimensional control.

\section{Types of Bracings}

Mainly there are two types of bracings are as follows;
A. Concentric bracings.

B. Eccentric bracings.

\section{OBJECTIVES}

The main objective of this project is to check and compare the seismic response of multi-storied building by using shear wall and steel bracings.

$>$ To validate the results of shear wall and bracings with available literature results.

$>$ To model G+9 storey building with shear wall and bracings using ETABS software.

$>$ To study storey displacement, storey drift, storey shear of both bracings and shear wall.

$>$ To model building in different seismic Zones like IV and $\mathrm{V}$.

$>$ To study shear wall and bracings at various location in R.C. Building modelled in E-TABS software.

\section{METHODOLOGY}

Methodology considered in this project is as follows:

$>$ Modelling of the G+9 storey building using ETABS v9.7 software.

$>$ Shear wall and bracings location at core, corner and center of the building.

$>$ Parameters considered in this project are storey displacement, storey drift, storey shear.

$>$ Seismic zones considered in this project are zone IV and Zone V.

\section{PARAMETERS CONSIDERED}

Parameters considering in this project are as follows:

\begin{tabular}{|l|l|}
\hline Number of stories & G+9 stories \\
\hline Thickness of slab & $150 \mathrm{~mm}$ \\
\hline Beam size & $300 \mathrm{~mm} \times 600 \mathrm{~mm}$ \\
\hline Column size & $600 \mathrm{~mm} \times 600 \mathrm{~mm}$ \\
\hline Wall thickness & $230 \mathrm{~mm}$ \\
\hline Bracings & ISA110mmX110mmX10mm \\
\hline Grade of concrete & $\mathrm{M} 25$ grade \\
\hline Live load & $3 \mathrm{KN} / \mathrm{m}^{2}$ \\
\hline Floor finish load & $1 \mathrm{KN} / \mathrm{m}^{2}$ \\
\hline Zones & $\mathrm{IV}$ and V \\
\hline
\end{tabular}

\section{BUILDING MODELS OF ZONE $\mathrm{V}$}

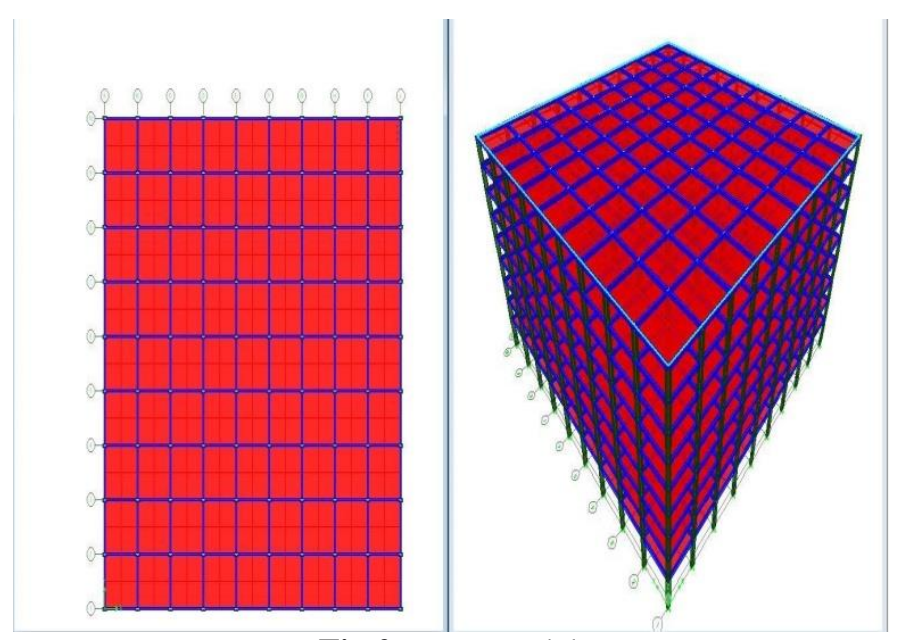

Fig 2: Bare Model

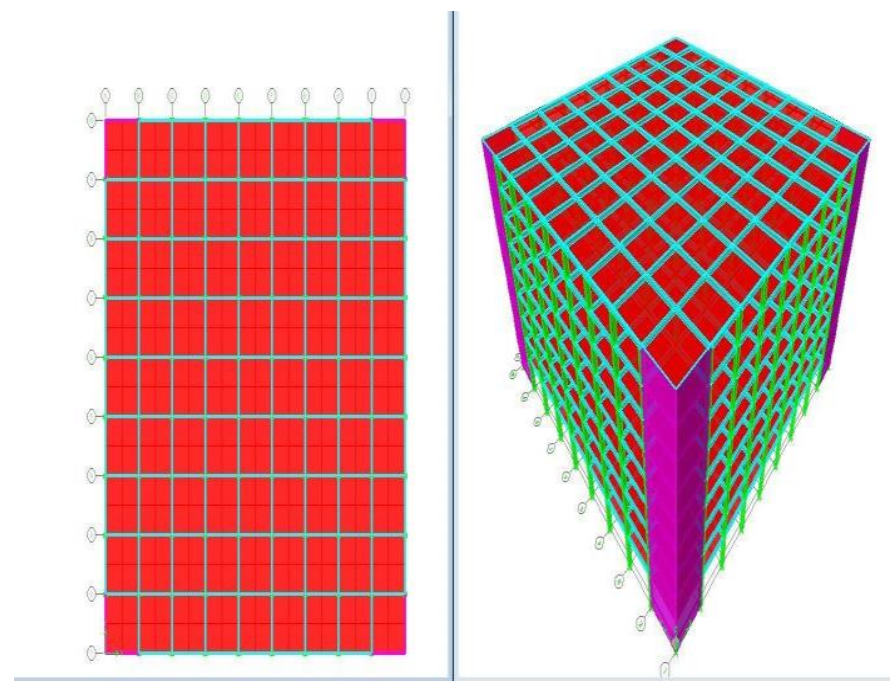

Fig 3: Shear Wall at Corner 


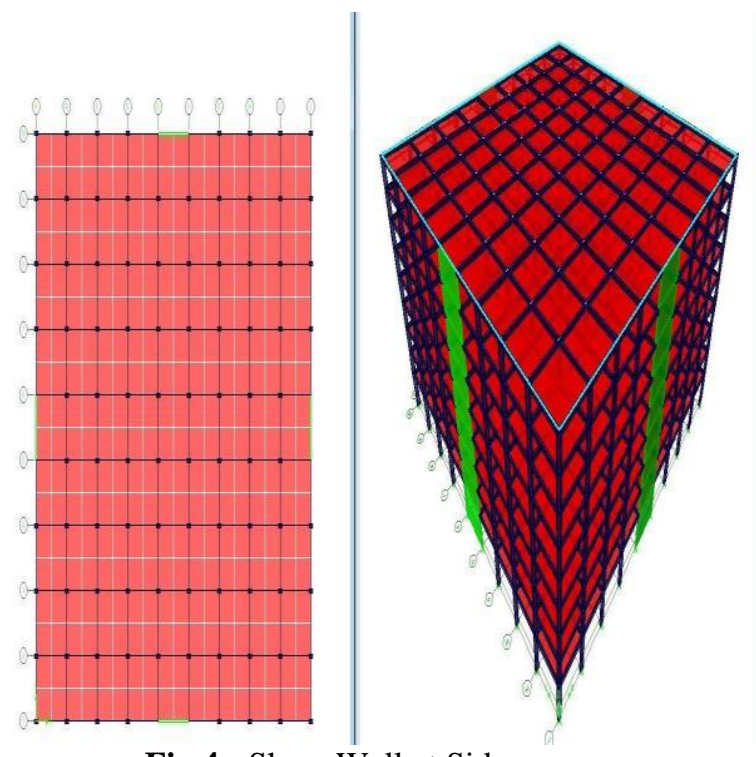

Fig 4: .Shear Wall at Sides

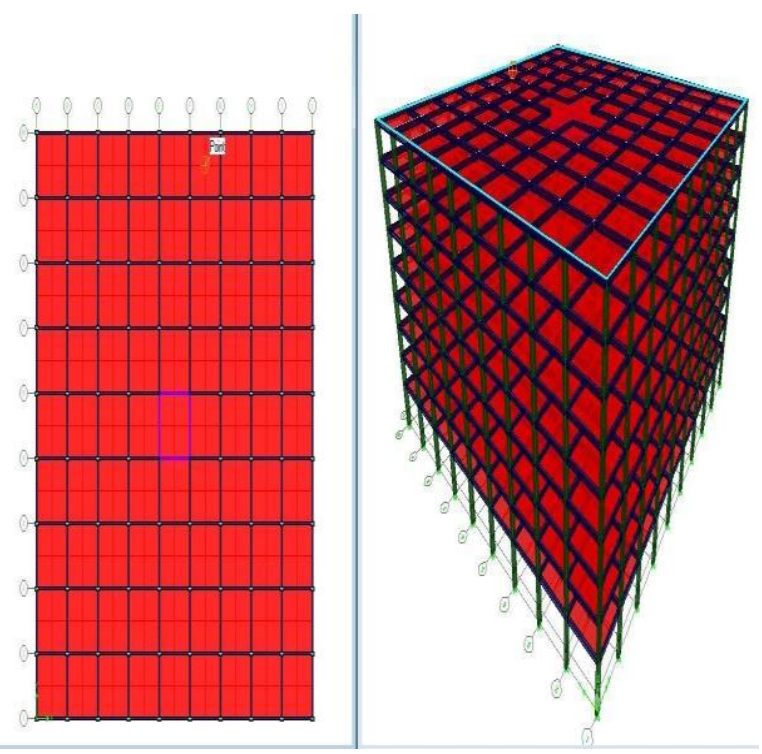

Fig 5: Shear Wall at Core

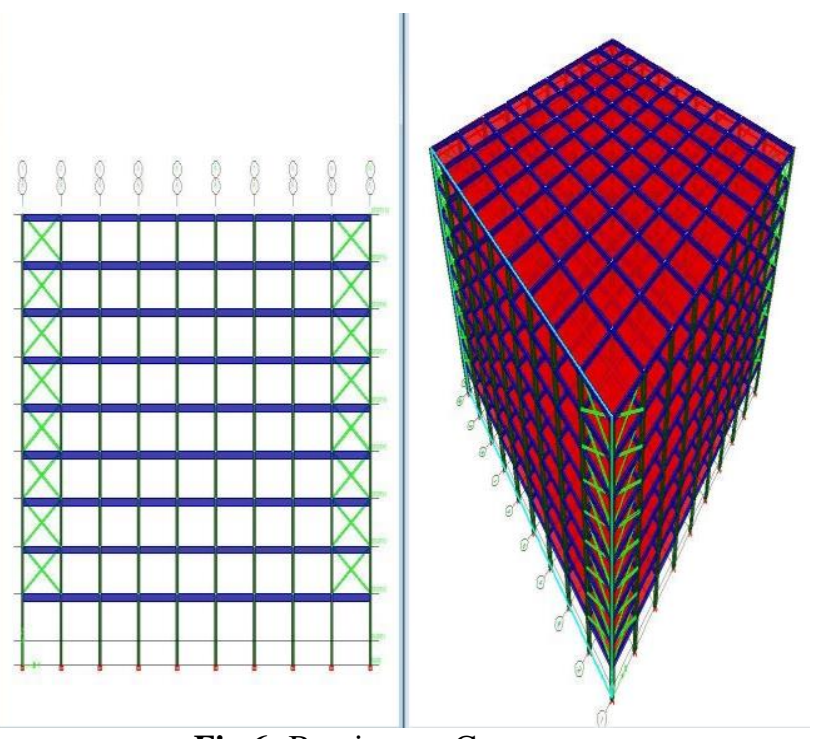

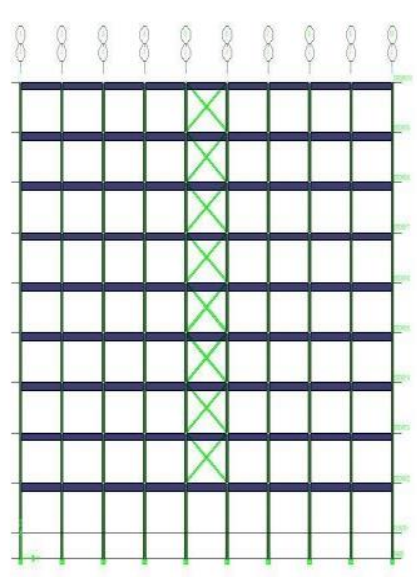

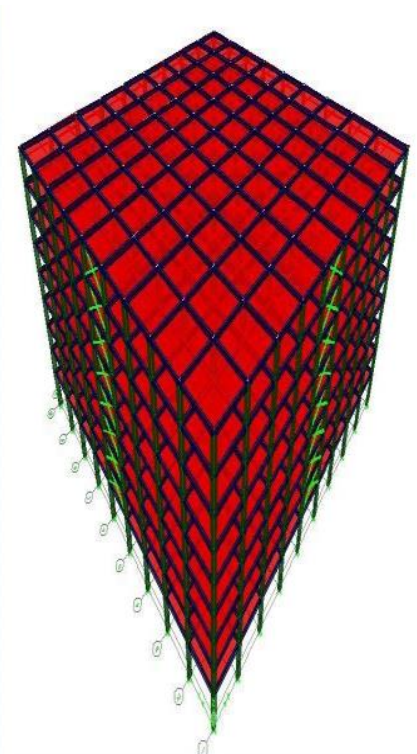

Fig 7: Bracings at sides

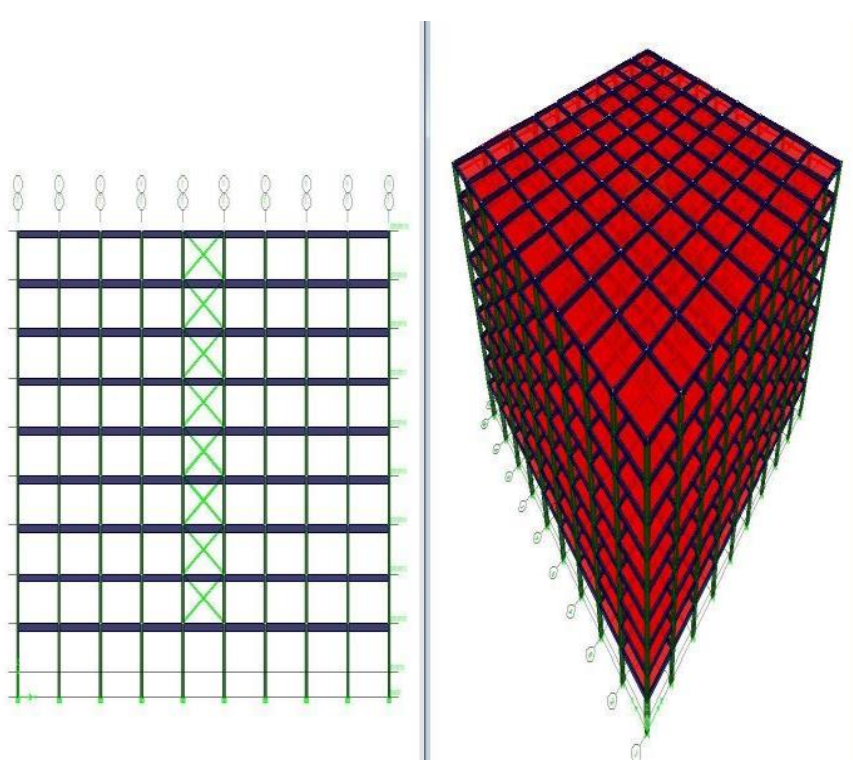

Fig 8: Bracings at Core

\section{RESULTS AND DISCUSSIONS}

The results have been compared with bare frame model of storey drift, storey displacement, storey shear with shear wall at corner, shear wall at sides, shear wall core, bracings at corner, bracings at sides and bracings at core.

Fig 6: Bracings at Corner 
Table 1: Storey drift for Zone-V in X-direction

\begin{tabular}{|l|l|l|l|l|l|l|l|}
\hline ST & BFM & SW-1 & SW-2 & SW-3 & BRC-1 & BRC-2 & BRC-3 \\
\hline 10 & 0.000353 & 0.000746 & 0.00066 & 0.000724 & 0.000404 & 0.000372 & 0.000367 \\
\hline 9 & 0.000573 & 0.000781 & 0.000762 & 0.000792 & 0.000578 & 0.000571 & 0.000568 \\
\hline 8 & 0.000769 & 0.000825 & 0.00088 & 0.000851 & 0.000737 & 0.000747 & 0.000744 \\
\hline 7 & 0.000921 & 0.00084 & 0.00097 & 0.000873 & 0.000855 & 0.00088 & 0.000878 \\
\hline 6 & 0.001031 & 0.000828 & 0.001028 & 0.000868 & 0.000934 & 0.000974 & 0.000972 \\
\hline 5 & 0.001106 & 0.000781 & 0.001042 & 0.000828 & 0.000981 & 0.001033 & 0.001032 \\
\hline 4 & 0.001151 & 0.000692 & 0.000994 & 0.000749 & 0.00101 & 0.001069 & 0.001068 \\
\hline 3 & 0.001183 & 0.00056 & 0.000861 & 0.000625 & 0.001075 & 0.001117 & 0.001123 \\
\hline 2 & 0.001211 & 0.000425 & 0.000672 & 0.000507 & 0.00127 & 0.001224 & 0.001222 \\
\hline 1 & 0.000573 & 0.000198 & 0.000577 & 0.000246 & 0.000607 & 0.000587 & 0.000595 \\
\hline
\end{tabular}

\section{STOREY DRIFT V/S STOREY}

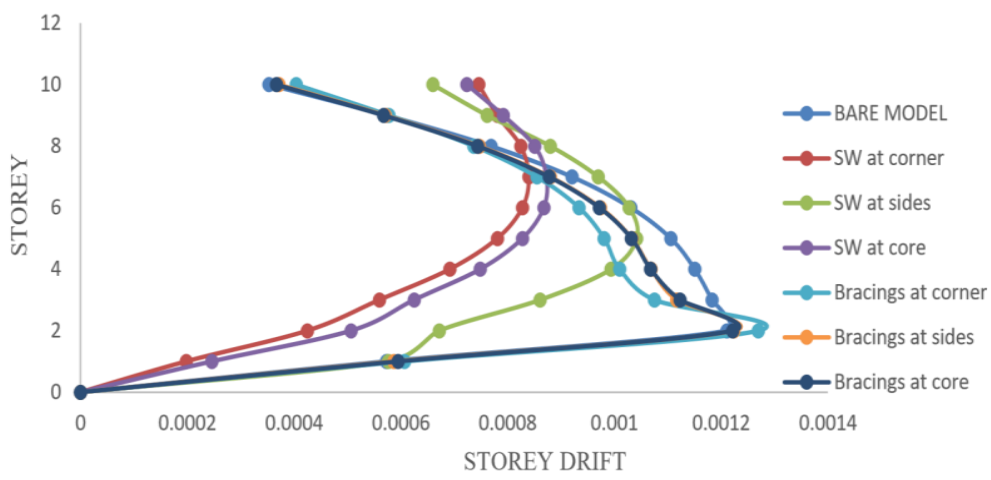

Graph 1: Storey drift V/S Storey for Zone V in X-direction

By plotting a graph of storey drift V/S number of storeys in $\mathrm{X}$ direction for ZoneV for medium soil type (soil-II). From graph, it is observed that bare frame is having maximum value when compared with shear wall at corners, shear wall at sides, shear wall at core, and it is having minimum value when compared with bracings at corners, bracings at sides, bracings at core. From table 1 it clears that the storey drift is decreased in model with shear walls and increased with bracings. Shear wall at corners it is decreased by $64.9 \%$, shear wall sides by $44.5 \%$, shear wall at core by $58.13 \%$ and bracings at corner it is increased by $4.04 \%$, bracings at sides by $1.06 \%$, bracings at core by $0.9 \%$.

Table 2: Storey displacement for Zone-V in X-direction

\begin{tabular}{|l|l|l|l|l|l|l|l|}
\hline ST & BFM & SW-1 & SW-2 & SW-3 & BRC-1 & BRC-2 & BRC-3 \\
\hline 10 & 0.03 & 0.0194 & 0.0236 & 0.0205 & 0.0241 & 0.0247 & 0.0248 \\
\hline 9 & 0.02 & 0.0174 & 0.0219 & 0.0185 & 0.023 & 0.0236 & 0.0246 \\
\hline 8 & 0.02 & 0.0151 & 0.0196 & 0.0161 & 0.0212 & 0.0219 & 0.0229 \\
\hline 7 & 0.02 & 0.0126 & 0.0169 & 0.0136 & 0.019 & 0.0197 & 0.0187 \\
\hline 6 & 0.02 & 0.0101 & 0.0141 & 0.011 & 0.0165 & 0.017 & 0.027 \\
\hline 5 & 0.01 & 0.0076 & 0.0109 & 0.0084 & 0.0137 & 0.0141 & 0.0131 \\
\hline 4 & 0.01 & 0.0053 & 0.0079 & 0.0059 & 0.0107 & 0.011 & 0.0121 \\
\hline 3 & 0.01 & 0.0032 & 0.0049 & 0.0037 & 0.0077 & 0.078 & 0.0079 \\
\hline 2 & 0 & 0.0015 & 0.0024 & 0.0018 & 0.0045 & 0.045 & 0.0046 \\
\hline 1 & 0 & 0.0003 & 0.0004 & 0.0003 & 0.0009 & 0.0009 & 0.0009 \\
\hline
\end{tabular}




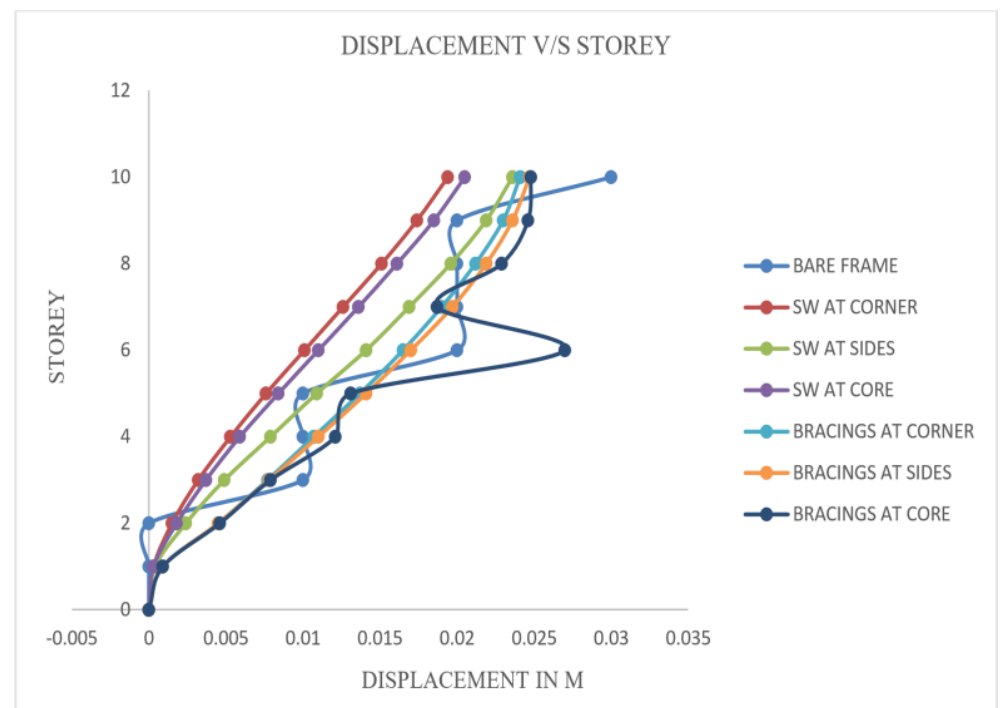

Graph 2: Storey displacement V/S Storey for Zone V in X-direction

By plotting a graph of storey displacement V/S number of storeys in $\mathrm{X}$ direction for zone- $\mathrm{v}$ for medium soil type (soilII). From graph, it is observed that bare frame is having maximum value when compared with shear wall at corners, shear wall at sides, shear wall at core, bracings at corners, bracings at sides, bracings at core. From table 3 it clears that the storey displacement is decreased in model with shear walls and bracings. Shear wall at corners it decreased by $35.33 \%$, shear wall sides by $21.33 \%$, shear wall at core by $31.66 \%$, bracings at corner by $19.66 \%$, bracings at sides by $17.67 \%$, bracings at core by $17.33 \%$.

Table 3: Storey shear for Zone-V in X-direction

\begin{tabular}{|l|l|l|l|l|l|l|l|}
\hline ST & BFM & SW-1 & SW-2 & SW-3 & BRC-1 & BRC-2 & BRC-3 \\
\hline 10 & 1011.74 & 1688.38 & 1251.68 & 1540.69 & 1086.75 & 1054.34 & 1055.24 \\
\hline 9 & 1874.32 & 3166.51 & 2329.67 & 2878.73 & 2013.88 & 1953.54 & 1955.19 \\
\hline 8 & 2545.88 & 4317.29 & 3168.94 & 3922.92 & 2735.69 & 2653.61 & 2655.85 \\
\hline 7 & 3050.3 & 5181.66 & 3799.32 & 4707.23 & 3277.86 & 3179.44 & 3182.12 \\
\hline 6 & 3411.45 & 5800.53 & 4250.66 & 5268.77 & 3666.03 & 3555.92 & 3558.92 \\
\hline 5 & 3653.21 & 6214.81 & 4552.79 & 5644.68 & 3925.89 & 3807.94 & 3811.16 \\
\hline 4 & 3799.46 & 6465.43 & 4735.57 & 5872.09 & 4083.08 & 3960.4 & 3963.75 \\
\hline 3 & 3874.08 & 6593.3 & 4828.82 & 5988.11 & 4163.29 & 4038.19 & 4041.6 \\
\hline 2 & 3900.94 & 6639.33 & 4862.39 & 6029.88 & 4192.14 & 4066.18 & 4069.62 \\
\hline 1 & 3901.21 & 6639.98 & 4862.78 & 6030.39 & 4192.43 & 4066.46 & 4069.9 \\
\hline
\end{tabular}




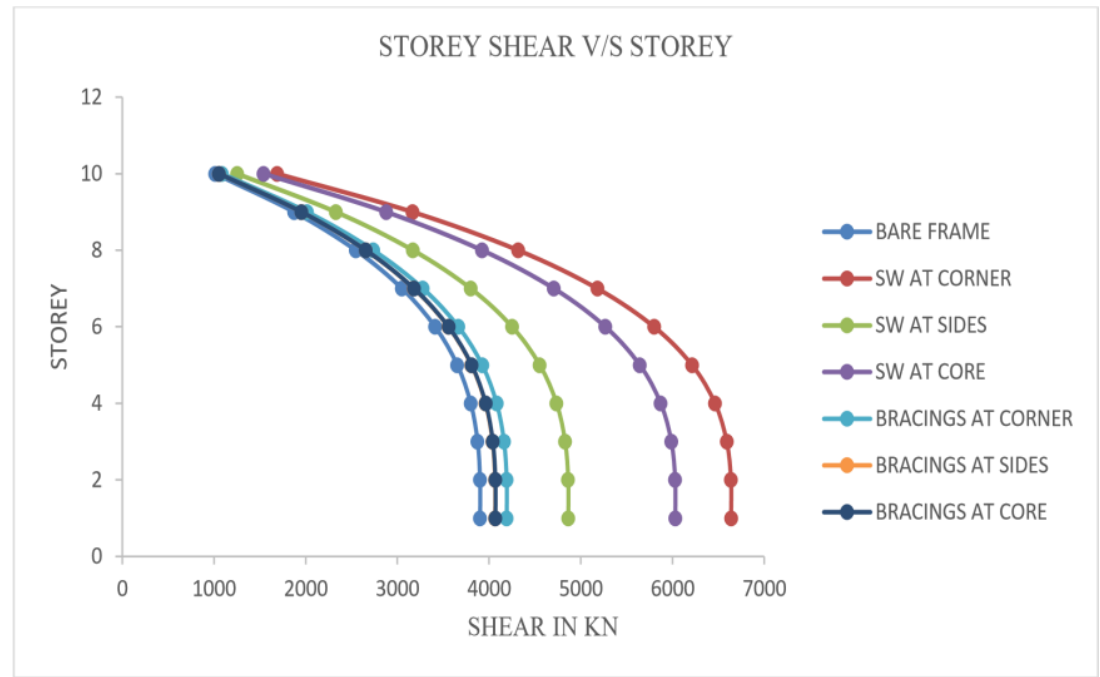

Graph 3: Storey shear V/S Storey for Zone V in X-direction

By plotting a graph of storey shear V/S number of storeys in $\mathrm{X}$ direction for zone-v for medium soil type (soil-II). From graph, it is observed that bare frame is having maximum value when compared with shear wall at corners, shear wall at sides, shear wall at core, bracings at corners, bracings at sides, bracings at core. From table, it clears that the storey shear is increased in model with shear walls and bracings. Shear wall at corners increased by $41.24 \%$, shear wall sides by $19.77 \%$, shear wall at core by $35.30 \%$, bracings at corner by $6.94 \%$, bracings at sides by $4.06 \%$, bracings at core by $4.14 \%$.

\section{DISCUSSIONS OF ZONE IV RESULTS}

Storey drift is decreased in model with shear walls and increased with bracings. Shear wall at corners it is decreased by $64.93 \%$, shear wall sides by $44.48 \%$, shear wall at core by $58.11 \%$ and bracings at corner it is increased by $4.72 \%$, bracings at sides by $1.10 \%$, bracings at core by $0.98 \%$.

Storey displacement is decreased in model with shear walls and bracings. Shear wall at corners it decreased by $24.56 \%$, shear wall sides by $8.18 \%$, shear wall at core by $20.46 \%$, bracings at corner by $5.84 \%$, bracings at sides by $3.50 \%$, bracings at core by $4.09 \%$.

Storey shear is increased in model with shear walls and bracings. Shear wall at corners increased by $52.47 \%$, shear wall sides by $30.60 \%$, shear wall at core by $46.65 \%$, bracings at corner by $25.44 \%$, bracings at sides by $29.20 \%$, bracings at core by $26.27 \%$.

\section{CONCLUSION}

1. Providing a shear wall element are more efficient in reducing lateral displacement of building as drift and horizontal deflection induced in shear wall are much less when compared with bare frame and bracings.

2. The location of shear walls at corner, at sides and bracings at corner has more significant effect on the seismic response than the bare frame.
3. Location of shear wall at corners are effective in reducing actions induced in frame with less deflection and drift.

4. Storey drift for Zone-V is decreased by $64.9 \%$ and in Zone-IV it is decreased by $64.93 \%$ for placing of shear wall at corners when compared with bare model frame.

5. Storey displacement for Zone-V is decreased by $35.33 \%$ and in Zone-IV, it is decreased by $24.56 \%$ for placing of shear wall at corners when compared with bare model frame.

6. Base shear value for Zone- $\mathrm{V}$ is increased by $41.24 \%$ and in Zone-IV, it is increased by $52.47 \%$ for placing of shear wall at corners compared to bare model frame.

From above results it is found that providing shear wall at corner gives more strength when compared with bare model frame and also with bracings.

\section{REFERENCES}

[1]. Alashker, Y., El-Tawil, S. and Sadek, F. (2015). "Progressive collapse resistance of steel-concrete composite floors," Journal of Structural Engineering, Vol. 136, No. 10, October 1, P1187-1196.

[2]. Mohd Atif ${ }^{1}$, Prof. Laxmikant Vairagade ${ }^{2}$ (2015), Comparative study on seismic analysis of multistorey building stiffened with bracing and shear wall. International Research Journal of Engineering and Technology (IRJET) ISSN: 2395-0056 www.irjet.net Volume: 02 Issue: 05, Aug2015 P-ISSN: 2395-0072

[3]. Ashwinkumar Balaso Karnale (2015), Comparative Seismic Analysis of High Rise and Low Rise RCC Building with Shear Wall, International Journal of Innovative Research in Science, Engineering and Technology, ISSN (Online) :2319-8753, ISSN (Print): 2347-6710 Vol. 4, Issue 9, September 2015

[4]. Shachindra Kumar Chadhar (2015), Comparative Study of RC Moment Resisting Frame of Variable Heights with Steel Bracing and Shear Wall, International Journal of Civil and Structural Engineering Research, ISSN23487607(online) Vol.3, Issue 1, PP: (220-221), Month: April 
2015-September 2015, Available at:

www.researchpublish.com

[5]. S.R. Thorat and P.J. Salunke (2014) "Seismic Behavior of Multistorey Shear Wall Frame Versus Braced Concrete Frames", International Journal of Advanced Mechanical Engineering, Volume 4, No 3, 2014, PP. 323-330

[6]. Shrikant Harle (2014) Analysis and Design of Earthquake Resistant Multi-Storied Braced R.C.C. Building using NISA Software, International Journal of Engineering Sciences \& Research Technology ISSN: 2277-9655 Impact Factor: 1.852 Harle, 3(1): January, 2014]

[7]. M. Ghalehnovi (2008) Comparison of Performance of Thin Steel Shear Walls and Concentric Braces by Capacity Spectrum Method, The $14^{\text {th }}$ World Conference on Earthquake Engineering October 12-17, 2008, Beijing,

China. 